\title{
ADDING PROBIOTICS TO RATIONS OF FATTENED CROSSBRED FRIESIAN CALVES AND ITS INFLUENCE ON CALVES' PERFORMANCE
}

\author{
El-Desokey ${ }^{1^{*}}$ W.M.S., Gado ${ }^{2}$ H.M., Abdrabbo ${ }^{1}$ M.A., and Metwally ${ }^{2}$ H.M.
}

1- Climate Change and Agric. Lab (CLAC), Agric. Research Center (ARC), Giza, Egypt

2- Animal Production Dept., Fac. of Agric. Ain Shams Univ., P.O. Box 68, Hadayek Shoubra 11241, Cairo, Egypt

*Corresponding author: waael_sc@yahoo.com

Received 4 May, 2019

Accepted 16 June, 2019

\section{ABSTRACT}

Fourteen male crossbred Friesian calves with an average initial (LBW) $288 \mathrm{~kg}$ were used in a fattening trial for 80 days, to study the effect of adding probiotics to untraditional feed rations of fattened male calves on their fattening performance. Experimental animals were randomly assigned into two nutritional groups ( 7 animals/ group) to be fed on citrus pulp silage, wheat germ, barley sprout and molasses, whereas calves of the treated group were daily supplemented in their ration with $10 \mathrm{ml} /$ calve/day probiotic (ZAD). Rations nutrients digestibility and fiber fraction, calves $A D G$, feed conversion ratio and boneless meat percentage were estimated. Results obtained showed that, adding probiotic ZAD to ration of treated calves group increased $(\mathrm{P}<0.05)$ digestibility of NDF and ADF percentages to 42.85 and 54.01 in treated ration in compare with 25.18 and 37.68 for the control group, respectively. Applying probiotic $(Z A D)$ to rations of the treated calves increased $(P<0.05) A D G$ in the hall fattened period to 1.011 , in compare with $0.886 \mathrm{~kg} / \mathrm{calve} /$ day in the control group; improving $(\mathrm{P}<0.05)$ calves feed conversion ratio (FC) to $(3.305 \mathrm{~kg}$ TDNI) in compare with $(4.579 \mathrm{~kg})$ for the control group, respectively; and insignificantly (FC) of DMl and CPI in calves of the treated group. Also, increased $(P<0.05)$ boneless meat percentage in carcasses of slaughtered treated calves to $51.10 \%$ in compare with $44.41 \%$ in the control carcass calves. In conclusion, supplementing silage of agriculture byproducts with ZAD probiotic, in presence of barley sprout, molasses and wheat germ results in improving rations nutrients digestibility, calves' growth performance and feed conversion ratio.
Keywords: Probiotics, ZAD, Fattened calves, Barley sprout

\section{INTRODUCTION}

It's expected through the next 100 years to show some climatic changes through two main ways, extreme weather events (i.e. sand storms, floods ... etc.) and global warming which characterizing "an increase in the global average surface temperature by $1.5-4.5$ Co" (Kuijpers, 1990).

According to (Smit et al 1996), and (Khalifa, $2003 \&$ 2012), animals are affected directly by weather and extreme event through animal health, growth, productivity, morbidity, and mortality. Also, animals are affected indirectly from dispreading of animal diseases and feed-grain competitiveness, availability, productivity, quality and price (i.e. livestock feed security).

Feeds represent $70 \%$ of the cost of an animal farms. Therefore, any negative change in the feed production process may be reflected the quality and/or quantity of the nutrients, and consequently increasing economic losses in animal production (Klein, 2009).

Some farmers in Egypt use new complementary and profitable feed techniques, also, noncompetitive with crop production by replacing the traditional feed resources, that include concentrate feed ingredients (i.e. maize and soybean), and forages totally with other feedstuffs based on crop residuals and wastes (Khalifa, 2012; Guessous et al 1989; and Gado et al 2009). Intensively using of mechanical, chemical and biological methods to increase the nutritional value were of great necessity when using roughage and 
forages in the feed stuffs (Guessous et al 1989; and Gado et al 2009).

Natural grain sprout such as barley sprout have an antioxidant activity and high levels of flavonoids (Park et al 2015). The major flavonoid identified in barley sprouts was saponarin (Lee et al 2015), which acts against development of hepatic steatosis and reduce hepatic triglyceride levels, (Kim et al 2017). Processing barley sprout feed increases growth performance (i.e. final BW, ADG, and Gain to feed ratio) of crossbred beef feedlot steers (Reed et al 2005).

Guessous et al 1989 and Gado et al 2009 reported that agriculture by-products and agromanufactory by-products are common in many countries of Mediterranean region especially Egypt, and it is frugal relative to its nutritive value. Such wastes and by-products constitute an economic hazard and environmental problems in regions if it is not managed ideally. It was reported by Food and Agriculture Organization of the United Nations (FAOSTAT, 2014), that orange is the most cultivated fruit in the world, for example in 2010 more than $68 \mathrm{Mt}$ were produced. The first producer is Brazil, followed by United States, India, China, Mexico, Spain, Egypt and Italy. The production of their countries represents $60 \%$ of the world production and it was higher than $2 \mathrm{Mt}$ per year. Negro et al 2017 discussed the unprofitability of the traditional handling techniques of orange pulp waste (e.g. composting and animal feeding) because of its bitterness and its low nutritional value of the high energy demand for the dehydration process. Therefore, increasing the nutritional value of orange peel composting, denies the reasons for lack of economic value and contributing to our overlapping feeding gap in Egypt.

Since it was stated that increased ruminal fiber digestion, often explains improvements in ruminant productivity resulting from dietary supplementation with fiber degrading enzymes (Gado et al 2009, Arriola et al 2011 and Holtshausen et al 2011). Recently it was focused by researchers in exogenous enzyme area supplemented on fibrolytic enzyme preparations and their positive effects on fiber digestion. Beauchemin et al 1995 reported that steers growth performance was improved by using such enzymes on dry forage.

As the impact of upcoming climate change scenarios on livestock feeding security (quality, availability, and price), applying alternative feedstuffs is a must. Fattening calves considered as a most process related to traditional feeding system. In the present study we purposed new feedstuffs for fattened calves consisting of citrus pulp silage, wheat germ, barley sprout and molasses. Within the above feedstuffs; mechanical, chemical, and biological treatments were used.

The present study aimed to investigate the effect of using probiotics $(Z A D \AA)$ with untraditional ration components on the performance of fattened male calves.

\section{MATERIALS AND METHODS}

The present study was conducted at a private farm within ELADLIA farms area, situated about 50 $\mathrm{km}$ north east of Cairo in Belbes, Sharkia Governorate. It lasted for 80 days from (15 July to 03 October 2014), but calves were purchased in 28 Jun 2014 which were maintained collectively in the farm to rehabilitate their rumen on the new suggested feed for 17 days before starting the study.

\section{Experimental animals}

Fourteen crossbred male Friesian calves purchased from local animal markets, in Kafr ElSheikh Governorate, were randomly assigned to two nutritional groups (7 calves each).

Calves were subjected to intensively veterinary program; treated against internal and external parasites, vaccinated and subjected to veterinary medical health insurance.

\section{Experimental animals' measurements}

Feed conversion ratio was calculated individually using the following equation ( $\left.\frac{\text { Amount of feed intake }}{\text { Weight gain }}\right)$.

Calves carcass boneless meat was calculated individually using the following equation, boneless meat $=$ (quantity of meat after slaughter / live slaughter weight or final weight) ${ }^{*} 100$.

\section{Feeding}

\section{Silage Ingredients and preparation}

Silage components were identified in Table (1). Aiming to mixing the previous components and improving their nutritional value, rice straw was shopped, placed as a layer via loader then a layer of orange peel and so on. ZADO probiotic was dissolved with molasses, urea and water, thin spreading on each layer via electrical pump till it's finished. After mixing the silage components, they were compressed and covered with plastic sheet, 
while bales of rice straw and stones were used to cover the plastic sheet.

Table 1. Silage components

\begin{tabular}{|l|c|c|}
\hline Item & Unit & Weight \\
\hline Molasses & $\mathrm{Kg}$ & 3000 \\
Urea & $\mathrm{kg}$ & 450 \\
Citrus pulp & $\mathrm{kg}$ & 24500 \\
Rice strew & $\mathrm{kg}$ & 11000 \\
Total & $\mathrm{kg}$ & 38950 \\
\hline
\end{tabular}

100 litters of liquid probiotic (ZAD) were added to silage compost.

Barley sprout Ingredients, methodology and management

Hydroponic barley sprout unit had been established, with a production capacity of half ton per day. Barley sprout grains were a germinated for seven days to attain the barley sprout yield. Hydroponic system consisted of connected iron shelves stand parallel, barrel with a capacity of one cubic meter of water, one horse power motor, timer for automation, network of different diameters of water ducts, quadruple exits with two micron diameter per each, and plastic sprout dishes with retinal holes. Two covers were used one cover for sun waves and the other is a plastic cover to avoid cold weather in winter.

As part of management technique, each day, we cultivate and putting the amount which is needed of barley sprouts and seeds, respectively. Aiming to reduce the water content, the cultivated sprout dishes were placed in the air for $24 \mathrm{hrs}$ before submitting to calves. Integrate with the optimal animal swallowed size; cutting sprout dishes at providing were implemented.

\section{Other proposed feed components}

Molasses and wheat germ were used. Both are manufacturing byproducts. Molasses nominated for increasing silage carbohydrate contents, administrate via spreading up on the orange peel silage. However, wheat germ nominated as a highly protein and vitamin source, administrated separately, at morning.

\section{Feeding management}

Experimental feed stuffs were offered to calves in three meals per day as following; first meal at 7:30 am which consisted of wheat germ; the second meal at 12am which consisted of dried particles of barley sprout, and the third meal at $6 \mathrm{pm}$, consisted of orange peel silage with molasses.

\section{Rations composition}

As shown in Tables (2 and 3), there are two feed formulas based on animals live body weight and coped with NRC crude protein requirements. The first formula was offered to fattened male calves during the growing period from $(288-311 \mathrm{~kg}$ live body weight), while the second formula was offered to fattened male calves during the finishing period from (312-400 kg live body weight).

\section{Proximate chemical analysis of rations ingredi- ents}

Chemical analysis of the proposed feed stuffs that's processed by Regional Center for Food \& Feed RCFF, Agricultural Research Center ARC, Giza, Egypt, are shown in Table (4).

Table 2. Ration composition offered to fattened male calves during the growing period (i.e. 288-311 kg live body weight)

\begin{tabular}{|l|c|c|c|c|c|c|}
\hline \multirow{2}{*}{ Feed stuff } & \multicolumn{2}{|c|}{ Feed Stuff NV(\%) } & \multicolumn{4}{c|}{ Daily feed intake / head / day (kg) } \\
\cline { 2 - 7 } & CP & TDN & As it is & DMI & CP & TDN \\
\hline Sprout & 15.06 & 60 & & & & \\
Silage & 12.35 & 60 & 8 & 2.23 & 0.28 & 1.34 \\
Wheat germ & 34.25 & 75 & 1 & 1 & 0.34 & 0.75 \\
Molasses & 6 & 75 & 1 & 1 & 0.06 & 0.75 \\
\hline Sum & & $\mathbf{2 0}$ & $\mathbf{5 . 6 8}$ & $\mathbf{0 . 9 0}$ & $\mathbf{3 . 7 1}$ \\
\hline
\end{tabular}


Table 3. Ration composition offered to fattened male calves during the finishing period (i.e. $312-400 \mathrm{~kg}$ live weight).

\begin{tabular}{|l|c|c|c|c|c|c|}
\hline \multirow{2}{*}{ Feed stuff } & \multicolumn{4}{|c|}{ Feed Stuffs NV(\%) } & \multicolumn{4}{c|}{ Daily feed intake / head / day (kg) } \\
\cline { 2 - 7 } & CP & TDN & As it is & DMI & CP & TDN \\
\hline Sprout & 15.06 & 60 & 14 & 2.03 & 0.31 & 1.22 \\
Silage & 12.35 & 60 & 8 & 2.23 & 0.28 & 1.34 \\
Wheat germ & 34.25 & 75 & 1 & 1 & 0.34 & 0.75 \\
Molasses & 6 & 75 & 2 & 2 & 0.12 & 1.50 \\
\hline Sum & \multicolumn{7}{|c|}{} & & $\mathbf{2 5}$ & $\mathbf{7 . 2 6}$ & $\mathbf{1 . 0 5}$ & $\mathbf{4 . 8 1}$ \\
\hline
\end{tabular}

Table 4. Chemical analysis of ration ingredients

\begin{tabular}{|l|l|l|l|l|l|l|}
\hline & Sprout & $\mathbf{U}^{\mathrm{a}} \pm$ & Silage & $\mathbf{U} \pm$ & Wheat Germ & $\mathbf{U} \pm$ \\
\hline Moisture \% & 85.5 & & 72.2 & & 11.8 & \\
E.E. \% & 3.02 & & 1.88 & & 9.4 & \\
Ash \% & 3.75 & & 9.4 & & 5.5 & \\
Crude Fiber \% ${ }^{\mathrm{b}}$ & 14.1 & 0.24 & 23.01 & 1.42 & 4.37 & 0.27 \\
Crude Protein \% ${ }^{\mathrm{c}}$ & 15.06 & 0.3 & 12.35 & 0.14 & 34.25 & 0.38 \\
NDF \% & 31.5 & 0.82 & 39.43 & 0.9 & 14.52 & 0.33 \\
ADF \% & 15.25 & 0.35 & 34.75 & 0.83 & 3.76 & 0.09 \\
ADL \% & 3.75 & 0.21 & 8.34 & 0.31 & 1.06 & 0.04 \\
Hemicelluloses \% & 16.15 & & 4.68 & & 10.76 & \\
Cellulose \% & 11.22 & & 26.42 & & 2.71 & \\
Lignin \% & 3.56 & & 5.55 & & 0.64 & \\
\hline
\end{tabular}

a: Estimated Uncertainty represent an expanded uncertainty (type A) expressed at approximately the 95\% confidence level using a coverage factor of $\mathrm{K}=2$,

b: Fiber were analyzed using ANKOM AOCS approved procedure Ba 6a-05 \& Instrument instruction manual of ANKOM 2000 fiber analyzer.

c: Protein were analyzed using AOAC official method of analysis, Dumas method No.968.06, chapter 4, P. 25-26, 19th ed. 2012 - Truspec Nitrogen Determinator instruction manual march (2006) Part number 200289, Kjeldahl method No.984.13, chapter 4, P. 31, 19th ed. 2012-Tecator.

\section{Digestion Measurements}

Chromium oxide (Cr2 O3) was resistant against rumen fermentation, therefore it's used as a marker. Chromium oxide dissolved in water and dissolved with wheat germ with considering mixing ratio of $2 \mathrm{gm}$ of chromium per $1 \mathrm{~kg}$ of wheat germ (i.e. $2 \mathrm{gm}$ of chromium/calve/day). Calves were fed on chromium for 14 days, individual fecal samples were taken after 10 days of feeding, while collected feces per each calve were dried and mixed. Based on Inductively Coupled Plasma atomic emission (ICP) manual instruction, two samples of dried fecal were taken from each calve and digested with concentrated sulfuric acid and hydrogen peroxide, placed in an ICP to determine concentrations of chromium with detection limits in parts per billion range, (Aceto et al 2002). The following digestion equation was used; digestible item ratio = (the amount of intake item - amount of item in faeces / amount of intake item) * 100 . Digestibilities were calculated for neutral detergent fiber (NDF), acid detergent fiber (ADF), acid detergent lignin (ADL), and crude protein (CP). 


\section{Statistical Analysis}

Complete random design was used. One way analysis of variance model for meat percent measures and with covariate term of initial claves body weight for other measurements were used. However, Data of the frequent average daily gains measurements analyzed using repeated measurements model.

General Liner Model (GLM) analyzer procedure and Mixed Liner Model (MIXED) analyzer procedure to account for within-subject (i.e. animal) covariability were used, (SAS, 2001). For detecting the significant differences among means, Duncan Multiple Range test (Duncan's, 1955) was used.

\section{RESULTS AND DISCUSSION}

Table 5. Effect of probiotic treatment on digestion coefficient values of nutrients

\begin{tabular}{|l|l|l|l|l|}
\hline \multirow{2}{*}{$\begin{array}{c}\text { Probiotic } \\
\text { treatment }\end{array}$} & \multicolumn{3}{|c|}{ Fiber Fractions } & \multirow{2}{*}{ CP } \\
\cline { 2 - 4 } & NDF & \multicolumn{1}{|c|}{ ADF } & ADL & \\
\hline Treated & $42.853^{\mathrm{a}}$ & $54.010^{\mathrm{a}}$ & 50.424 & 79.172 \\
Control & $25.180^{\mathrm{b}}$ & $37.679^{\mathrm{b}}$ & 39.310 & 76.731 \\
\hline S.E. & $\mathbf{7 . 0 9 2}$ & $\mathbf{3 . 7 7 4}$ & $\mathbf{8 . 0 4 1}$ & $\mathbf{6 . 9 5 0}$ \\
\hline
\end{tabular}

a \& b: Means within a column without a common superscript differ significantly $(\mathrm{P}<0.05)$.

Citrus pulp and rice straw silage considered as a basic dry matter source. Due to using of ZAD probiotic (in the liquid form) by side with other chemical additives (Urea and molasses) within silage components, silage crude protein reached $12.35 \pm 0.14 \%$, the matter which might be referred to significant increase in nutrients digestibility.

Data in Table (5) showed the effect of probiotic treatment on digestion coefficient ratio of feed nutrients, (i.e. crude protein and fiber fraction values). Results indicated that NDF and ADF of treated group tended to be higher $(P<0.05)$ than that of the control group, while ADL and CP tended to be insignificantly improved. Similar digestibility result was obtained by (Gado et al 2009, 2011 and 2013) and Salem et al (2013), when applying probiotics on sheep. Similar fiber degradation results were obtained in vitro by (Gado et al 2006 and 2013), when adding $Z A D$ on feed or ensiled rice straw. Salem et al 2013 and Gado et al 2011 concluded that supplementing ensiled orange pulp with ZAD probiotics increased $(P<0.05)$ nutrient digestibility values.

Table 6. Effect of probiotic treatment on fattened male calves feed conversion ratios

\begin{tabular}{|l|l|l|l|}
\hline $\begin{array}{l}\text { Probiotic } \\
\text { treatment }\end{array}$ & DMI & CPI & TDNI \\
\hline Treated & 6.689 & 1.037 & $3.305^{\mathrm{b}}$ \\
Control & 7.186 & 1.051 & $4.579^{\mathrm{a}}$ \\
\hline S.E. & $\mathbf{0 . 6 0 9}$ & $\mathbf{0 . 1 3 1}$ & $\mathbf{0 . 6 5 3}$ \\
\hline
\end{tabular}

a \& b: Means within a column without a common superscript differ significantly $(P<0.05)$, DMI: Dry Matter Intake, CPI: Crude Protein Intake, TDNI: Total Intake of Digestible Nutrients, all data where calculated based on the following equation (amount of item / weight gain).

Significant relationship was found between Initial Weight (IW), as a covariate term effect withq TDNI, resulting the following deterministic prediction equation;

\section{$T D N I$ conversion ratio $=-10.858+0.054 \mathrm{IW}$.}

Data in Table (6) showed the effect of probiotic treatment on feed conversion ratio of fattened male calves.

Results indicated that DMI and CPI of the control group tended to be higher insignificantly than that of the treated group. However, TDNI was higher $(\mathrm{P}<0.05)$ in the control group $(4.579 \mathrm{~kg})$ compared with treated group (3.305 kg). Similar results were found (i.e. an improvement in feed conversion ratio) when using probiotics produced from anaerobic fermentation of Ruminococcus Flavefaciens on growing lambs, (Gado, and Salem, 2008). 
Table 7. Effect of probiotic on daily gain $(\mathrm{kg})$ and boneless meat percentage of fattened male calves

\begin{tabular}{|l|l|l|l|l|l|}
\hline $\begin{array}{l}\text { Probiotic } \\
\text { treatment }\end{array}$ & ADG & ADG2 & ADG3 & Aggregate ADG & Boneless meat \\
\hline $\begin{array}{l}\text { Periods } \\
\text { (days) }\end{array}$ & 46 & 17 & 17 & 80 & 80 \\
$\begin{array}{l}\text { Treated } \\
\text { Control }\end{array}$ & $1.063^{\mathrm{a}}$ & 1.025 & $0.856^{\mathrm{b}}$ & $1.011^{\mathrm{a}}$ & $51.097^{\mathrm{a}}$ \\
\hline S.E. & $0.686^{\mathrm{b}}$ & 0.899 & $1.413^{\mathrm{a}}$ & $0.886^{\mathrm{b}}$ & $44.140^{\mathrm{b}}$ \\
\hline
\end{tabular}

a\&b: Means within a column without a common superscript differ significantly $(P<0.05), S . E$. is the standard error.

Data in Table (7) showed the effect of probiotic on daily gain and boneless meat percentage of fattened crossbred Friesian male calves.

Results indicated that the Average Daily Gain (ADG) of treated group was significantly higher than the control group through the first and aggregate growing period and insignificantly during the second growing period. However, the control group showed the highest values through the third fattening period. On the other hand, boneless meat percentage was significantly higher $(P<0.05)$ in treated group $(51.10 \%)$ compared with the control group (44.14\%). Lara et al., (2018) found significant improvement in lambs' growth performance, when using corn silage with Lactobacillus plantarum and Bacillus subtilis, but with a little effect on carcass and meat traits. Similar results were reported by (Gado et al 2009, 2011 and 2013; Salem et al 2013 and Hassan et al 2019) in sheep production performance when using ZAD probiotics.

It can be concluded that probiotics may act as repartitioning agent towards lean tissue.

\section{CONCLUSION}

On the light of the present results, it was concluded that supplementing fattened male calves ration with $Z A D^{\circledR}$ probiotic in presence of barley sprout, wheat germ and molasses, improved significantly $(\mathrm{P}<0.05)$ calves feed conversion ratio, ADG in the hall fattened period (1.011) in compare with $(0.886 \mathrm{~kg} / \mathrm{calve} /$ day $)$ in the control group, and also, increased the percent of boneless meat from $(44.41 \%)$ to $(51.10 \%)$

In conclusion, adding $Z A D^{\circledR}$ probiotic to silage of agriculture byproducts, resulted in improving rations nutrients digestibility.

\section{REFERENCES}

Aceto M., Abollino O., Bruzzomiti M.C., Mentasti E., Sarzanini C. and Malandrino M. 2002. Determination of metals in wine with atomic spectroscopy (flame-AAS, GF-AAS and ICP-AES); a review, Food Additives and Contaminants 19(2), 126-133.

Arriola K.G., Kim S.C., Staples C.R. and Adesogan A.T. 2011. Effect of fibrolytic enzyme application to low- and high-concentrate diets on the performance of lactating dairy cattle. J. Dairy Sci. 94, 832-841.

Beauchemin K.A., Rode L.M. and Sewalt V.J.H. 1995. Fibrolytic enzymes increase fiber digestibility and growth rate of steers fed dry forages. Can. J. of Animal Sci. 75, 641-644.

Duncan N.B. 1955. Multiple ranges and multiple F test. Biometrical, 11, 1-42.

FAO STAT 2014. Statistical Database of the Food and Agriculture Organization of the United Nations.<http://faostat.fao.org > (accessed 05.10.14).

Gado H.M., Sohair A. Nasr, Bahira, K. Mohamed and Mahrous A.A. 2006. Effect of biological treatmentson the nutritive value of rice straw. Egyptian J. Nutrition and Feeds 9(2), 207219.

Gado H.M. and Salem A.Z.M. 2008. Influence of exogenous enzymes from anaerobic source on growth perform- ance, digestibility, ruminal fermentation and blood metabolites in lambs fed of orange pulp silage in total mixed ration. In: $59^{\text {th }}$. Annual Meeting of the European Association for Animal Production, Vilnius, Lithuania, August 24-27, 228 p. 

influence on calves' performance

Gado H.M., Salem A.Z.M., Robinson P.H. and Hassan M. 2009. Influence of exogenous enzymes on nutrient digestibility, extent of ruminal fermentation as well as milk production and composition in dairy cows. Anim. Feed Sci. Technology. 154, 36-46.

Gado H.M., Salem A.Z.M., Odongo N.E. and Borhami B.E. 2011. Influence of exogenous enzymes ensiled with orange pulp on digestion and growth performance in lambs. Animal Feed Sci. and Technology, 165, 131-136.

Gado H.M., Salem A.Z.M., Camacho L.M., Elghandour M.M.Y. and Salazar M.C. 2013. Influence of Exogenous Enzymes on In Vitro Ruminal Degradation of Ensiled Rice Straw with DDGS. Animal Nutrition and Feed Technology 13, 569-574.

Guessous F., Rihani N., Kabbali A. and Johnson W.L. 1989. Improving feeding system for sheep in a Mediterranean rainfed cereals/livestock area of Morocco. J. of Animal Sci. 67, 3080-3086.

Hassan A., Gado H., Uchenna Y. Anele, Maria A.M. Berasain, and Salem A.Z.M. 2019. Influence of dietary probiotic inclusion on growth performance, nutrient utilization, ruminal fermentation activities and methane production in growing lambs. J. of Animal Biotechnology, 103, 1-8.

Holtshausen L., Chung Y.H., Gerardo-Cuervo H., Oba M. and Beauchemin K.A. 2011. Improved milk production efficiency in early lactation dairy cattle with dietary addition of a developmental fibrolytic enzyme additive. J. Dairy Sci. 94, 899-907.

Khalifa H.H. 2003. Bioclimatology and Adaptation of Farm Animals in a Changing Climate. Interactions Between Climate and Animal Production, Satellite Symposium $54^{\text {th }}$ Annual Meeting EAAP, September $4^{\text {th }}$. pp. 20-26.

Khalifa H.H. 2012. Assessment of climate change impacts on livestock. FAO Project No. UNJP/EGY/022. pp. 19-30.

Kim Y.J., Su Hyeon Hwanga, YaoyaoJiaa, WooDuck Seob and Sung-Joon Lee. 2017. Barley sprout extracts reduce hepatic lipid accumulation in ethanol-fed mice by activating hepatic AMP-activated protein kinase. Food Research International 101, 209-217.

Klein A. 2009. Analise de Pontoscríticos do controle de qualidadeemfabricas de raçao. Revista
Eletronica: Nutritime. Analysis of critical points of quality control in sugar factories. Nutritime Magazine: 6(5), 97-102.

Kuijpers, L.J.M., 1990. UNEP assesment of the Montreal protocol: Refrigeration within the framework of the technology review. Int. J. of Refrigeration,13(2), 95-99.

Lara E.C., Bragiato U.C., Rabelo C.H.S., Messana J.D., Sobrinho A.G.S. and Reis R.A. 2018. Inoculation of corn silage with Lactobacillus plantarum and Bacillus subtilis associated with amylolytic enzyme supply at feeding. 2. Growth performance and carcass and meat traits of lambs. J. of Animal Feed Sci. and Technology, 243, 112-124.

Lee J.H., Lee S.Y., Kim B., Seo W.D., Jia Y., Wu C. and Lee S.J. 2015. Barley sprout extract containing policosanols and polyphenols regulate AMPK, SREBP2 and ACAT2 activity and cholesterol and glucose metabolism in vitro and in vivo. Food Research International, 72, 174-183.

Negroa V., Ruggeria B.D. and Finoa T.D. 2017. Life cycle assessment of orange peel waste management. Resources, Conservation \& Recycling 127, 148-158.

Park M.J., Seo W.D. and Kang Y.H. 2015. The antioxidant properties of four Korean barley cultivars at different harvest times and profiling of major metabolites. J. of Agric. Sci., 7(10), 9496.

Reed J.J., Bauer M.L., Loe J.S. and Caton L.G.P. 2005. Effects of Processing on Feeding Value of Sprouted Barley and Sprouted Durum Wheat in Growing and Finishing Diets for Beef Cattle. The Professional Animal Scientist. 21(1), 7-12.

Salem A.Z.M., Gado H.M., Colombatto D. and Eghandour M.M.Y. 2013. Effect of exogenous enzymes on nutrient digestibility, ruminal fermentation and growth performance in beef steers. Livestock Sci. 154(1-3), 69-73.

SAS, 2001. Users Guide: Statistics (Release 8.01). SAS Inst. Inc., Cary, NC, USA.

Smit B., Mcnabb D. and Smihers J. 1996. Agriculture adaptation to climatic variation. Climate Change, 33, 7-29.

Steinfeld H., Gerber P., Wassenaar T., Castel V., Rosales M. and Haan C. 2006. Livestock's Long Shadow: Environmental issues and options. FAO Agriculture Technical paper, Rome, Italy, Chapter pp. 111-122. 


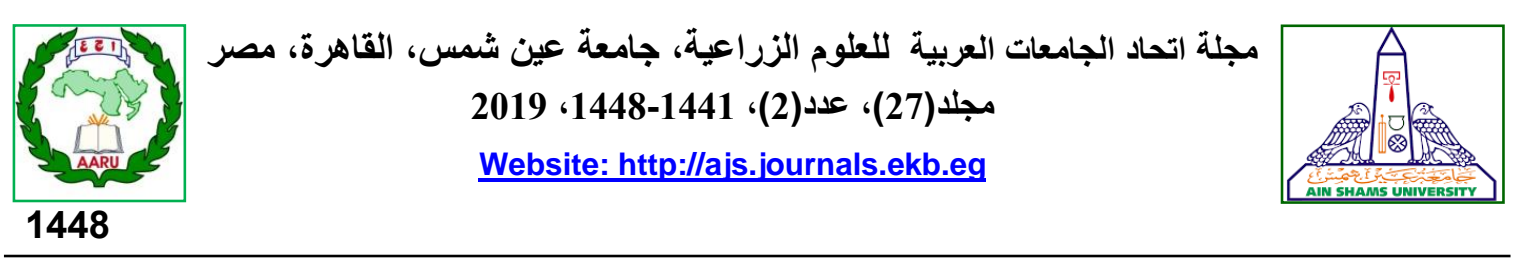

تأثير إضافة البروبيوتك إلى علائق تسمين العجول الفريزيان الخليطه على كفاءة أداءها

$$
\begin{aligned}
& \text { وائل محمد صلاح الاسوقي 1" - هاني محمود جادو2 - محمد أحمد عبدريه1 - حمدي محمد متولي2 } \\
& \text { [118] }
\end{aligned}
$$

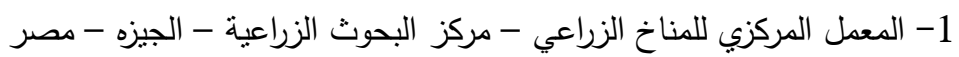

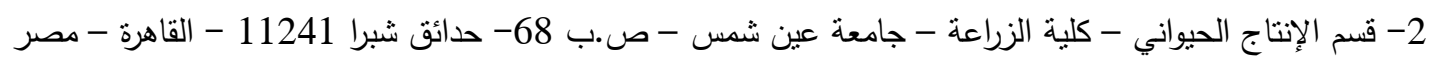

*Corresponding author: waael_sc@yahoo.com

Received 4 May, 2019 Accepted 16 June, 2019

فروق معنويه إيجابية نتيجة لإستخدام البروبيوتلك في

زيادة معدلات النمو خلال فترة التسمين بمعدل 1.011 لإنيا

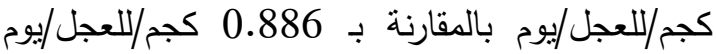

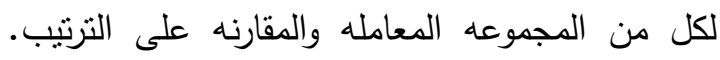
وارتفعت نسبة اللحم المشفى بالذبائح بشكل معنوي الكعائ بواقع 51.097\% للعجول بالمجموعة المعاملة مقارنة بالفئة

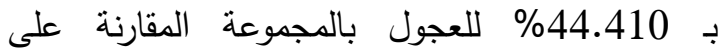

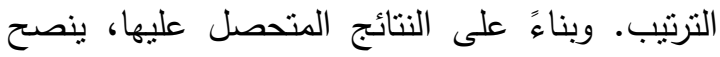

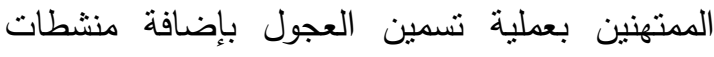
النمو (بروبيوتك زاد) على المخلفات الزراعية في وجود

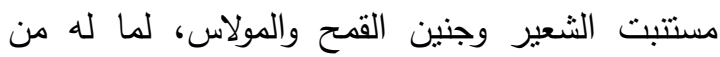
تأثثرات إيجابية على تحسين القيمة الهضميه والغذائية

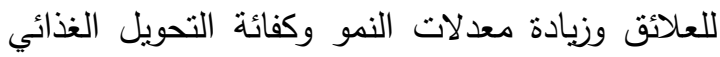

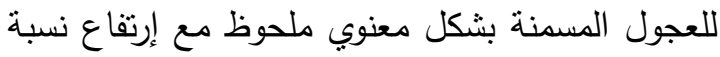
النشافي لللحوم بالذبائح .

الكلمات الدالة: بروبيوتك، زاد، تسمين العجول، مستنبت الثعير

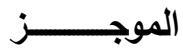

تؤثر التغيرات المناخية المتوقعه في مجال تغذية الحيوان على الأمان العلفي للحيوانات من حيث (وفرة الأعلاف و جودتها وسعرها) مما يستلزم وبشده إستخدام

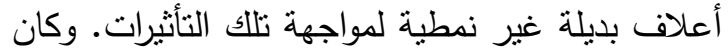
الهدف من الدراسة إستخدام موارد علفيه جديدة غير اعلير نمطيه لتغذية عجول التسمين تشمل (مكمورة تقل البرتقال وجنين القمح ومستتبث الشعير والمولاس). واستخدام في عمل المكمورة بعض وفين المعاملات الميكانيكيه والكيميائية والبيولوجية. وفيها نم تقييم كفاءة التسمين لعدد (14 عجل ذكر خليط فريزيان) في تجربة تسمين لمدة 80 يوم، حيث قسمت العجول عشول فئئياً بواقع 7 عجول بكل مجموعة. بونة ونم تقديم 10

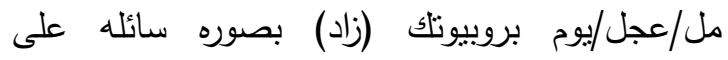
الأعلاف المقدمه للمجموعه المعامله. تم تقييم الأعلاف المقترحه المستخدمه من حيث قيمتها الهضميه والغذائيه

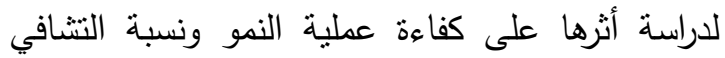
للذبائح وكان من أهم النتائج المتحصل عليها عليها وجود 